\title{
Oil Price Shocks and Macroeconomic Activities in Asean-5 Countries: A Panel VAR Approach
}

\author{
Mukhriz Izraf Azman AZIZ*, Jauhari DAHALAN ${ }^{* *}$
}

\begin{abstract}
The paper investigates the asymmetric effects of oil price shocks on real economic activities in ASEAN-5 from 1991 to 2014 using an unrestricted panel Vector Auto Regressive (VAR) method. Results from the impulse response function (IRFs) show evidence of an asymmetric relationship between oil prices and economic activities. Specifically, positive oil price shock measures negatively affect output growth both in the short term and in the long term. For oil price decrease specifications, real output responds negatively in the short term before recovering to its pre-shock level in the long term. The variance decomposition analysis (VDCs) also exhibit differences between the effects of positive and negative oil price shocks on economic activities, supporting the evidence of asymmetric relationship obtain in the IRFs simulations.
\end{abstract}

Key Words: Oil Price Shocks, International Trade

JEL codes: F11, N50

UDC: 339.5: 339.923

* School of Economics, Finance and Banking, Universiti Utara Malaysia, Malaysia.

E-mail:mukhriz@uum.edu.my

** School of Economics, Finance and Banking, Universiti Utara Malaysia, Malaysia

E-mail: djauhari@uum.edu.my

Copyright (C, 2015 International Ataturk Alatoo University. 


\section{Introduction}

Historically oil plays a unique role in the world economy, and it is still true today. Since the middle of the twentieth century, crude oil has become a chief indicator of economic activity worldwide, because of its importance as the source of global energy. Since oil was commercially discovered in $1859,{ }^{1}$ there has been numerous studies conducted on oil and its relation to the economy, society, and environment. Early literatures on oil price shocks on the oil-importing US economy found a statistically significant negative linear relationship with the output. These studies include Rasche and Tatom (1981), Hamilton (1983), Burbidge and Harrison (1984), among others. Later studies on the non-US economies also found statistically significant oil price-output relationship (Eksi, Izgı, \& Sentürk, 2011; Cavalcanti \& Jalles, 2013; Ju, K., et al., 2014; Negi, 2015)

By mid-1980s, however, the estimated linear relationship between oil prices and real activity began to lose significance. In fact, the declines in oil prices that occurred over the second half of the 1980s had smaller positive effects on economic activity than predicted by linear models. Thus, Mork (1989), Lee et al. (1995), and Hamilton (1996) introduced non-linear transformations of oil prices and established an asymmetric (non-linear) relationship between increases in oil prices and output growth. Recently, a nonlinear relation between oil prices and subsequent real GDP growth has been reported for a number of countries (Rahman \& Serletis, 2010; Berument, Ceylan \& Dogan, 2010; Engemann, Kliesen \& Owyang, 2010; Hamilton, 2011).

Despite the non-linear (asymmetric) relationship found between oil price shocks and macroeconomic variables in oil-importing economies, studies on oil-exporting countries have shown that this relationship is in fact symmetric (linear). Eltony and Al-Awadi (2001) found evidence that symmetric oil price shocks are important in explaining fluctuations in macroeconomic variables in Kuwait. Berument et al. (2010) studied the effects of symmetric oil price shocks on output (proxied by industrial production) for a group of Middle East and North African countries. Their impulse response analyses suggest that the effects of world oil price on GDP of Middle Eastern countries are positive and statistically significant. In a study by Jbir and Zouari-Ghorbel (2009), no evidence was found of asymmetric effects of oil price shocks on the Tunisian economy, as no difference in terms of results was discovered between the linear and non-linear vector autoregressive (VAR) models.

In spite of the growing interest on the oil price-macro economy nexus among OECD and Middle East economies, study on emerging Asian economies is still lacking. Recent studies on ASEAN countries in particular produced mixed results. For example, Basnet and Upadhyaya (2015) discovered that oil price shock is not the

\footnotetext{
${ }^{1}$ Oil historians in the US give credit for the first modern commercial oil well to Colonel Edwin L. Drake. His well reached a depth of $22 \mathrm{~m}$ (72 ft). It was drilled in "Oil Creek" near the town of Titusville, slightly east of Pittsburgh, Pennsylvania, US, and started producing oil on 28 August 1859.
} 
major impediment of economic growth in ASEAN-5 countries. On the contrary, Vu and Nakata (2014) showed that in terms of output and price variabilities, the oil importing countries such as Singapore, Thailand and the Philippines are more sensitive to the situation in the world oil market than the oil exporting countries such as Indonesia and Malaysia. These findings prompt further investigation because for most developing countries, oil accounts for a large proportion of gross domestic product expenditures in energy production (González \& Nabiyev, 2009). As a result, increases in energy prices lead to a considerable rise in production and transportation cost for many industries and hence drives wages and inflation upwards, which at the same time can dampen economic growth (O'Neill, Penm \& Terrell, 2008). Accordingly, this study attempts to address this issue for five core economies of South East Asia, namely Indonesia, Malaysia, the Philippines, Singapore and Thailand (henceforth denoted as ASEAN-5) during the period of 1991 to 2014. Among the ASEAN-5 countries, Malaysia and Indonesia are net oil exporters. Oil exports contribute around 6 percent and 9 percent respectively for Malaysia's and Indonesia's annual domestic revenue. Singapore although without any oil resource has a booming oil refinery industry that accounts for 6 percent of the city-state's economy. The Philippines despite being a net oil-importing country consumes oil only a third of that of Thailand (International Energy Agency, 2011), thus making the former's economy less exposed to oil price increases.

This paper therefore aims to determine whether the macroeconomic volatility in ASEAN-5 countries is due to fluctuations in oil prices. Specifically, the paper attempts to establish whether the impact of oil price shocks on ASEAN-5's macroeconomic variables are symmetric or asymmetric. This is achieved using a panel of five-variable VAR model with quarterly data from 1991:1 to 2014:4. The paper employs impulse response functions (IRFs) to determine what impacts an oil price shock would have on the variables in the model, how long such effects would last, and when the maximum repercussions could be expected. To take into account the asymmetric effect of oil prices, the paper estimates the relationship between oil prices and macroeconomic variables using the standard linear and three non-linear approaches. These are (1) quarterly oil price changes, (2) separate oil price variables for price increases and decreases, as in Mork (1989), (3) scaled oil price increases and decreases, as in Lee at al. (1995), and (4) net specification as in Hamilton (1996), which considers the amount by which oil prices have risen over the previous year.

The present study extends the existing empirical literature on the ASEAN economy in several directions. First, it complements the works of Basnet and Upadhyaya (2015) and Cunado and de Gracia (2005) on the oil price-macroeconomy relationship. Although Basnet and Upadhyaya (2015) study included the ASEAN-5, he did not examine the asymmetric effect of oil price shocks for these economies when using the VAR approach. In contrast, Cunado and de Gracia (2005) tested for asymmetric effects of oil prices for several ASEAN countries, but the estimation was 
carried out using an autoregressive distributed lag (ARDL) model. Thirdly, the paper assesses the relationship between oil prices shocks and macro economy using panel VAR approach, which inherits the advantage from traditional VAR model that treats all the variables in the system as endogenous. Moreover, the panel VAR procedure also has the advantage from panel-data framework that allows for unobserved individual heterogeneity for all the variables by introducing fixed effects which enhances the consistency of the estimation.

The main results of the paper may be summarised as follows. First, the linear (symmetric) oil price specification reveals that changes in oil price stimulate GDP growth in the short term, but cause GDP to decline in the long term. Second, for non-linear (asymmetric) specifications, positive oil price shocks cause GDP to decline in the long term without experiencing growth in the short term. Another interesting finding is the response of output growth to negative (decreasing) oil price changes. Using negative oil price shock measures, GDP responds negatively in the short term, but eventually recovers although responses in the long term are not statistically significant.

When comparing the results between the linear and non-linear IRF simulations, the paper finds substantial difference between these two approaches. In other words, there is evidence of asymmetric relation between oil price and the macroeconomic activities in ASEAN-5. Additionally, the variance decomposition of the non-linear VAR shows that the rise and fall in oil prices have different impacts on real output growth, pointing to an asymmetric relationship between oil prices and economic activities. Thus, the paper finds strong evidence on the asymmetric impacts of oil price shocks on macroeconomic activities in ASEAN-5.

This paper begins with a brief discussion on the theoretical background of the demand and supply sides' impacts of oil price shocks and discusses how asymmetry in oil price shocks arise. Data and method are discussed in the next section. This is followed by presentation of empirical results as well as the analysis of the findings. Finally, concluding remarks are given at the end of the paper.

\section{Theoretical Framework}

\subsection{Demand and Supply Sides' Impacts of Oil Price Shocks}

Fluctuations in oil prices have negative repercussions on the aggregate economy, as shown by economic literature. An oil price shock, as an example of an adverse supply shock, results in a rise in price level and a reduction in output and employment (Dornbusch et al., 2001). On the other hand, aggregate demand decreases as higher commodity prices translate to lower demand for goods and services, resulting in contraction in aggregate output and employment levels. The macroeconomic effects of oil shocks are transmitted via supply and demand side channels and are potentially minimised by economic policy reactions. 
Since oil is a factor of production in most sectors and industries, a rise in oil prices increases companies' production costs and thus stimulates contraction in output (Jimenez-Rodriguez and Sanchez, 2005). Given a firm's resource constraints, the increase in the price of oil as an input of production reduces the quantity it can produce. Hunt et al. (2001) add that an increase in input costs can drive down nonoil potential output supplied in the short run given existing capital stock and sticky wages. Moreover, workers and producers may respond to the decline in their real wages and profit margins by putting upward pressure on unit labour costs and the prices of finished goods and services.

As discussed earlier, oil price increases translate to higher production costs, leading to commodity price increases. Higher commodity prices then translate to lower demand for goods and services, therefore shrinking aggregate output and employment. Furthermore, higher oil prices affect aggregate demand and consumption in the economy. The transfer of income and resources from oilimporting to oil-exporting economies is projected to reduce worldwide demand as demand in the former is likely to decline more than it will rise in the latter (Hunt et al., 2001). This is particularly true when the marginal propensity for oil importers to consume is higher than that of oil exporters. The resulting lower purchasing power of the oil-importing economy translates to a lower demand for goods and services. In sum, an increase in oil prices causes a leftward shift in both the demand and the supply curve, resulting in higher prices and lower output.

\subsection{Why Does Asymmetry Effects of Oil Shock Arise?}

High oil prices affect open economies both directly and indirectly. The indirect effect works through an economy's trading partners. For example, in the ASEAN-5, Malaysia and Indonesia are net oil exporters and major trading partners of Singapore. Singapore is an oil importer. While higher oil prices impact negatively on Singapore's GDP growth, Malaysia and Indonesia reap the benefits in terms of higher export revenues. This in turn increases their imports from Singapore. The net effect of oil prices on Singapore, therefore, depends on the magnitude of these direct and indirect effects.

The linearity or symmetric assumption between real oil prices and macroeconomic variables (for oil importing countries) implies that if oil price increases causes economic recession, then oil price declines must cause an economic expansion with the same magnitude, although in reverse direction. On the other hand, the asymmetric effects of oil price shocks assume that a decrease in oil price may actually lower future GDP growth through other channels. Hamilton (1988) suggests that asymmetry could be the result of adjustment costs to changing oil prices. Falling oil prices stimulate economic activity, and rising oil prices impede economic activity, but the costs of adjusting to changing in oil prices also impede economic activity. Combining these elements, it can be seen that rising in oil prices 
would present two negative effects for economic activity. Falling in oil prices would present both a negative and a positive effect which would tend to be offsetting.

Another possibility is that monetary policy may account for the asymmetric response of aggregate economic activity. The way monetary policy is conducted plays a significant role in how the consequence of oil-price shocks play out in the economy. Leduc and Sill (2004) and Jumah and Pastuszyn (2007) among others, argue that contractionary monetary policy following an oil price increase accounts for the decline in aggregate economic activity. Ferderer (1996) suggests a third possibility. Uncertainty and financial pressure brought on by changing oil prices could amplify the negative effects of rising oil prices and offset to some degree the positive effects of falling oil prices.

\section{Data and Method}

\subsection{Data}

The paper uses quarterly panel data for the period 1991:1 to 20014:4 for four macroeconomic variables (defined below) and four measures of oil price shocks. The four measures of oil price shocks are quarterly oil price changes (DLOGROIL), Hamilton's (1996) Net Oil Price Increase (NOPI), Lee et al.'s (1995) Scaled Oil Price Increase (SOPI) and Decrease (SOPD), and Mork's (1989) Oil Price Increase and Decrease. All variables are expressed in logs and US dollar (except oil price shocks variables). The data sets were obtained from International Finance Statistics (IFS). The variables used in the paper are real gross domestic product (GDP), real exports (EXPORT), real imports (IMPORT), inflation (CPI) and oil price shock. The oil price shock variables are divided into-linear and non-linear-measures. Section 3.2 discusses the oil price variables in further detail

The choice of four macroeconomic variables is based on work by Farzanegan and Markwardt (2009). However, real industrial GDP variables as employed in Farzanegan and Markwardt (2009) are substituted with real GDP. The use of GDP is consistent with previous literature (see Lee et al., 1995, and Hamilton, 2003, among others). Table 1 provides descriptive statistics of four series used in the panel VAR analysis.

Table 1. Descriptive statistics

\begin{tabular}{cccccc}
\hline Variables & Mean & Std. Dev. & Minimum & Maximum & Observations \\
\hline GDP & 250099 & 457905 & 940 & 2103136 & 472 \\
EXPORT & 25964 & 26006 & 675 & 121049 & 480 \\
IMPORT & 32383 & 18185 & 8776 & 90119 & 480 \\
CPI & 77.94 & 24.70 & 13.29 & 128 & 480 \\
\hline
\end{tabular}

\subsection{Oil Price Shock Variables}

A number of studies have used different oil price variables to account for the effects of these shocks on economic activity. According to studies on the US 
(Hamilton, 1996; Mork, 1989; Lee et al., 1995), the effect of oil prices on growth is asymmetric. Thus, by defining the real oil price in time $t$ as $\operatorname{roil}_{i t}=\log \left(O^{*} E_{i t} / C P I_{i t}\right)$, where $O$ is Dubai crude oil price in US\$, $E_{i t}$ is the exchange rate of each of ASEAN-5 country against US\$, and $C P I_{i t}$ is the consumer price index of ASEAN-5 countries, the paper estimates the effects of oil price shocks using linear and non-linear specifications of a panel VAR model. The linear specification of oil price is based on quarterly changes in real oil prices, that is, the conventional first difference transformation of oil price variables (in logs):

$D L O G R O I L_{i t}=$ roil $_{i t}-$ roil $_{i t-1}$

where roil $_{i t}$ is the real oil price (in logs) in local currencies, as defined above. On the basis of asymmetric oil effects, this paper also uses three non-linear specifications of oil prices: 1) separate oil price variables for price increases and decreases, as in Mork (1989); 2) net specification (Hamilton, 1996 and 2003), where the relevant oil price variable is defined as the net amount by which these prices in quarter $t$ exceed the maximum value reached in the previous four quarters; and 3) scaled oil price increase and decrease, proposed by Lee et al. (1995).

In Mork (1989), the asymmetric specification distinguishes between the positive rate of change in the oil price and their negative rates of change are defined as follows:

MORK INCREASE $=\max \left(0,\left(\right.\right.$ roil $\left._{i t}-\operatorname{roil}_{i t-1}\right)$
MORK DECREASE $=\min \left(0,\left(\right.\right.$ roil $\left._{i t}-\operatorname{roil}_{i t-1}\right)$

Hamilton (1996) proposed a different non-linear transformation, using an explanatory variable called net oil price increase (NOPI). This is defined as the amount by which oil prices in quarter $t$, roil ${ }_{t}$, exceed the maximum value over the previous four quarters, and zero otherwise. That is:

$N O P I_{i t}=\max \left\{0, \operatorname{roil}_{i t}-\max \left\{\operatorname{roil}_{i t-1}, \operatorname{roil}_{i t-2}, \operatorname{roil}_{i t-3}, \operatorname{roil}_{i t-4}\right\}\right\}$

Hamilton's (1996) definition is also asymmetric in the specific sense that it captures oil price increase-type shocks while neglecting the impact of oil price declines. This is inspired by earlier evidence that oil price decreases played a smaller role in the US business cycle. Lee et al. (1995) argued that oil price shock is likely to have greater impact on real GNP in an environment where oil prices are stable than in one where oil price movements are frequent and erratic. The $\operatorname{AR}(4)-\operatorname{GARCH}(1,1)$ model is calculated as below:

$$
\begin{aligned}
& \Delta \operatorname{roil}_{i t}=\beta_{0}+\beta_{1} \Delta \text { roil }_{i t-1}+\beta_{2} \Delta \text { roil }_{i t-2}+\beta_{3} \Delta \text { roil }_{i t-3}+\beta_{4} \Delta \text { roil }_{i t-4}+\varepsilon_{i t} \\
& \varepsilon_{i t} \mid I_{i t-1} \sim N\left(0, h_{i t}\right) \\
& h_{i t}=\gamma_{0}+\gamma_{1} e_{t-1}^{2}+\gamma_{2} h_{t-1} \\
& \operatorname{SOPI}_{i t}=\max \left(0, \hat{\mathrm{e}}_{i t} / \sqrt{\hat{\mathrm{h}}_{i t}}\right) \\
& \operatorname{SOPD}_{i t}=\min \left(0, \hat{\mathrm{e}}_{i t} / \sqrt{\hat{\mathrm{h}}_{i t}}\right)
\end{aligned}
$$


Where SOPI is scaled oil price increase, while SOPD denotes scaled oil price decreases. The scaled model builds on the asymmetric model, where it employs a transformation of the oil price that standardises the estimated residuals of the autoregressive model by its time-varying (conditional) variability. This transformation seems very plausible in light of the pattern of oil price changes over time, with most changes being rather small and punctuated by occasional sizeable shocks (Jiménez-Rodríguez and Sánchez, 2005).

\subsection{Estimation Method}

The paper uses panel VAR techniques developed by Love and Ziccino (2006) to estimate the variance decompositions and the impulse response functions. The panel VAR approach inherits the advantage from traditional VAR model that treats all the variables in the system as endogenous. Moreover, the panel VAR procedure also has the advantage from panel-data framework that allows for unobserved individual heterogeneity for all the variables by introducing fixed effects which enhances the consistency of the estimation. This panel VAR model can be specified as follows:

$X_{i t}=\eta(L) X_{i t}+\mu i+\varepsilon_{i t}$

where $X_{i t}$ is a vector of stationary variables, $\eta(L)$ is a matrix polynomial in the lag operator with $\eta(L)=\eta_{1} L^{1}+\eta_{2} L^{2}+\ldots . .+\eta_{n} L^{n}, \mu_{i}$ is a vector of time invariant, country specific effects and $\varepsilon_{\text {it }}$ is a vector of idiosyncratic errors. Due to lagging dependent variables, the fixed effects are correlated with the repressors. Hence, if one uses the mean-differencing method to eliminate fixed effects, then the coefficients would be biased. To avoid this problem, the paper uses forward meandifferencing (the Helmert procedure or orthogonal deviations) (see Arellano and Bover, 1995), following Love and Zicchino (2006). Note that this procedure removes only the forward mean, i.e. the mean of all the future observations available for each individual quarter. Since the transformation preserves the orthogonality between transformed variables and lagged repressors, one can use lagged repressors as instrumental variables and estimate the coefficients by GMM system.

Upon the estimation of all the coefficients of the panel VAR, the impulse response functions (IRFs) and the variance decompositions (VDCs) are computed. Given a forecast time horizon, variance decompositions measure the contributions of each source of shock to the (forecast error) variance of each endogenous variable. The impulse response functions describe the reaction of one variable to changes in the innovations of another variable in the system, while holding all other shocks equal to zero. The main assumption here is that variables listed earlier in the VAR order affect the other variables contemporaneously, while variables listed later in the VAR order affect those listed earlier after a lag. Since isolated shocks to individual variables cannot be identified, because of contemporaneous correlation, the responses of a variable to innovations in another variable of interest cannot be adequately represented (Lütkepohl, 2007). 
To account for this difficulty, Sims (1980) recommends attempting triangular orthogonalizations using the Cholesky decomposition. In specific, the variables that appear earlier in the ordering are more exogenous which will affect the following variables contemporaneously or even with a lag, while the variables come later in the systems are more endogenous that only affect the previous variables with a lag. In view of that, this paper uses the Cholesky decomposition and classifies the variables from the most exogenous to the less exogenous. Assuming prices are flexible, the panel VAR ordering is set as:

$X_{i t}=$ (Oil Price Shock Variable, CPI, EXPORT, IMPORT, GDP)

In the baseline ordering, the real oil price shock variable is ranked as largely exogenous. This is because ASEAN-5's oil production and exports account for less than $3 \%$ of estimated total world oil output, hence ASEAN-5 countries are incapable of influencing global oil prices. Furthermore, demand for crude oil is largely determined by global economic growth, speculator operations in oil markets, and the policies of key oil consumers on strategic petroleum reserves. The second variable in the ordering is CPI. This ordering allows the price level (CPI) to adjust contemporaneously to shocks in oil prices. Changes in price level are feed thru EXPORT and IMPORT and finally changes in GDP.

\section{Empirical Results}

The first step of the analysis is to look at the properties of the data. To test for the presence of the panel unit root, the following test results are reported: Im-PesaranShin (IPS) test (Im, Pesaran, \& Shin, 2003), Breitung (2000) and Levin, Lin and Chu (2002) tests.

\subsection{Test of Stationarity}

Table 2 provides the unit root regression results at level and first difference of the variables entered in the model and the corresponding critical value of $10 \%, 5 \%$, or $1 \%$ to reject the null hypothesis of the presence of a unit root. The panel unit root tests statistics in Table 2 suggest that all four variables are integrated of order one $\mathrm{I}(1)$, whereas the first differences are integrated of order zero $I(0)$. These nonstationary variables were transformed by taking their first differences in order to exhibit stationarity. As for the oil price shocks variables (DLOGROIL, MORK INCREASE \& MORK DECREASE, NOPI, SOPI \& SOPD), they are by definition stationary at levels because of the construction of the variables themselves. Each oil price measure is derived from taking the first difference (or the change) between the present value and the past value of the price of oil according to the oil price variable specification. Further, given the different orders of integration for the variables involved in the analysis, it may produce misleading results if a cointegrated VAR is estimated. Therefore, the paper carries out an unrestricted panel VAR at levels for these variables with five lag, as found to be optimal by most 
lag selection test criteria ${ }^{2}$. This approach (i.e VAR at levels in the presence of mixed orders of integration among variables) follows the work of Mallick and Mohsin (2007, 2010).

\section{Table 2. Panel unit root tests for panel ASEAN-5}

\begin{tabular}{|c|c|c|c|c|}
\hline Variables & GDP & EXPORT & IMPORT & $\mathrm{CPI}$ \\
\hline \multicolumn{5}{|l|}{ Series at level } \\
\hline Levin, Lin, and Chu t-stat $^{a}$ & $\begin{array}{l}0.8015 \\
(0.788)\end{array}$ & $\begin{array}{l}0.5289 \\
(0.701)\end{array}$ & $\begin{array}{l}0.3699 \\
(0.644)\end{array}$ & $\begin{array}{l}-0.1637 \\
(0.435)\end{array}$ \\
\hline Breitung t-stat ${ }^{a}$ & $\begin{array}{l}0.0193 \\
(0.507)\end{array}$ & $\begin{array}{r}-1.4933 \\
(0.067) \\
\end{array}$ & $\begin{array}{l}-2.2145 \\
(0.013) \\
\end{array}$ & $\begin{array}{l}1.6853 \\
(0.954)\end{array}$ \\
\hline Im, Pesaran, and Shin w-stat ${ }^{b}$ & $\begin{array}{l}-0.3024 \\
(0.381) \\
\end{array}$ & $\begin{array}{c}-0.0744 \\
(0.4703)\end{array}$ & $\begin{array}{l}-0.4447 \\
(0.3283)\end{array}$ & $\begin{array}{l}1.1975 \\
(0.884)\end{array}$ \\
\hline \multicolumn{5}{|l|}{ Series at first difference } \\
\hline Levin, Lin, and Chu t-stat $^{a}$ & $\begin{array}{c}-26.991 \\
\left(0.000^{* *}\right) \\
\end{array}$ & $\begin{array}{c}-22.216 \\
\left(0.000^{* * *}\right)\end{array}$ & $\begin{array}{c}-17.226 \\
\left(0.000^{* * *}\right)\end{array}$ & $\begin{array}{c}-9.1798 \\
\left(0.000^{* * *}\right)\end{array}$ \\
\hline Breitung t-stat $^{a}$ & $\begin{array}{c}-12.067 \\
\left(0.000^{* * *}\right)\end{array}$ & $\begin{array}{c}-13.153 \\
\left(0.000^{* * *}\right)\end{array}$ & $\begin{array}{c}-10.323 \\
\left(0.000^{* * *}\right)\end{array}$ & $\begin{array}{c}-4.6501 \\
\left(0.000^{* * *}\right)\end{array}$ \\
\hline Im, Pesaran, and Shin w-stat ${ }^{b}$ & $\begin{array}{c}-21.00 \\
\left(0.000^{* * *}\right)\end{array}$ & $\begin{array}{c}-19.521 \\
\left(0.000^{* * *}\right)\end{array}$ & $\begin{array}{c}-14.166 \\
\left(0.000^{* * *}\right)\end{array}$ & $\begin{array}{c}-7.5190 \\
\left(0.000^{* * *}\right)\end{array}$ \\
\hline
\end{tabular}

Notes: An intercept and trend are included in the test equation. The lag length was selected using the Modified Akaike Information Criteria. The numbers in the bracket are the $p$-values of the corresponding test statistics. ${ }^{*}(* *) * * *$ denote statistical significance at the $10 \%, 5 \%$ and $1 \%$ levels.

${ }^{a}$ Signifies that the null hypothesis is the unit root (with the assumption that the cross-sectional units share a common unit root process).

${ }^{\mathrm{b}}$ Signifies that the null hypothesis is the unit root assuming that the cross-sectional units have individual unit root processes.

\subsection{Impulse Response Functions Results}

In order to analyse the impulse-response functions (IRF), the estimation of the confidence intervals for the IRF is required. Since the impulse-response functions are constructed from the estimated VAR coefficients and their standard errors, Monte Carlo simulations are employed to generate the confidence intervals based on the estimated coefficients and the standard errors. The $5^{\text {th }}$ and $95^{\text {th }}$ percentiles of the distribution of the generated coefficients from 200 bootstraps are used as the confidence interval for the impulse responses. Figure 1 illustrate the IRFs based on one standard deviation shock to the linear and non-linear oil price shocks measures for 1991:1 to 2014:4. The IRFs generated from the panel VAR model using the linear specification of crude oil prices (DLOGROIL) in the $1^{\text {st }}$ row of Figure 1 shows that a positive oil price shock increase CPI, GDP, EXPORT and IMPORT in the first two quarters after the initial shock. This increase is statistically significant for all variables. However, such increase does not last long (i.e. real GDP, real exports and real imports decline after the second quarter). This decline is however not statistically significant for all variables.

\footnotetext{
${ }^{2}$ On the basis of different lag order selection criteria, the paper found lag 5 to be the optimum lag length by HQ (Hannan Quinn information criterion) and SC (Schwarz information criterion).
} 
Oil Price Shocks and Macroeconomic Activities in Asean-5 Countries: A Panel VAR Approach
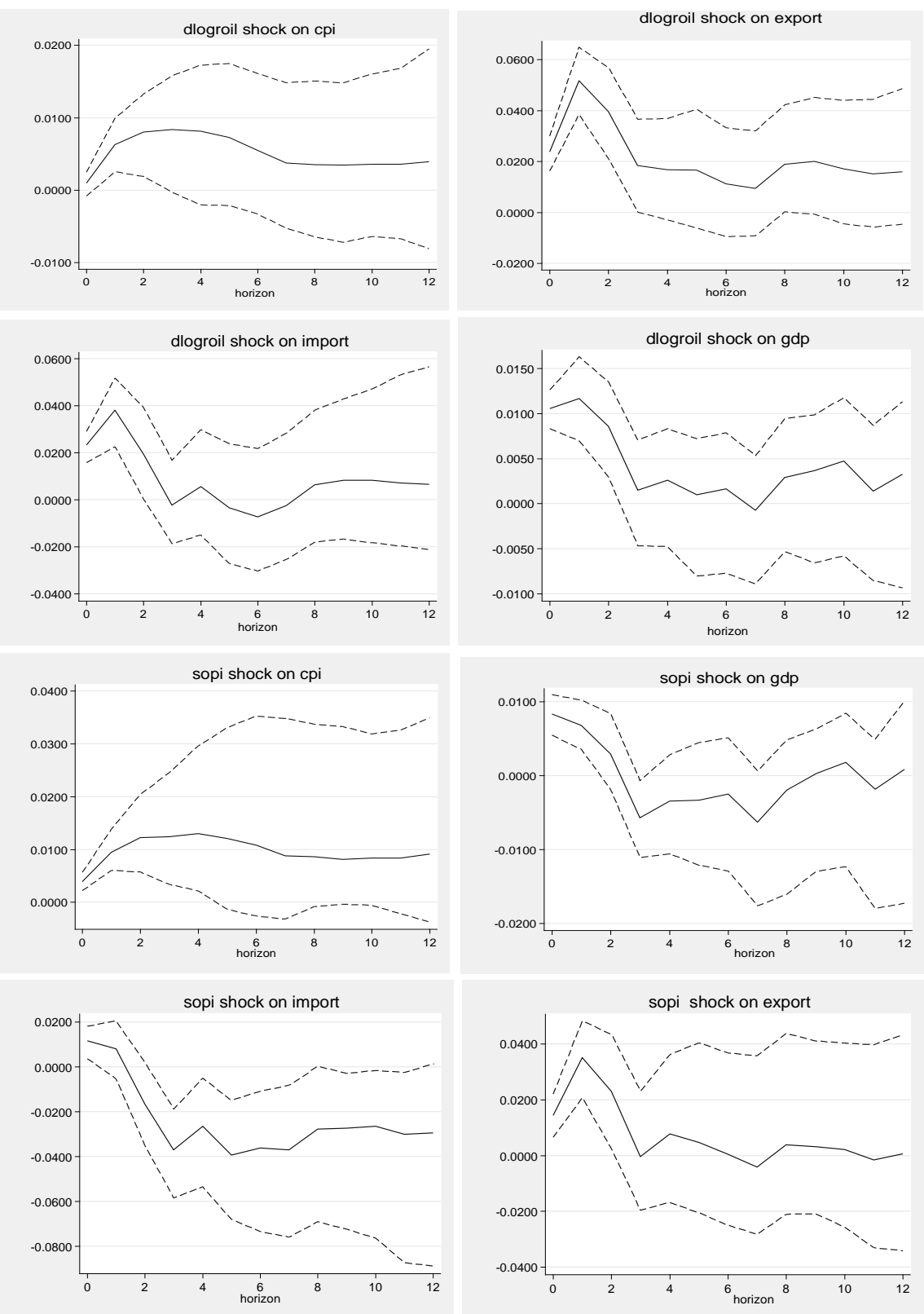

Figure 1. Impulse Responses of Oil Price Shocks Variables on CPI,EXPORT, IMPORT \& GDP 

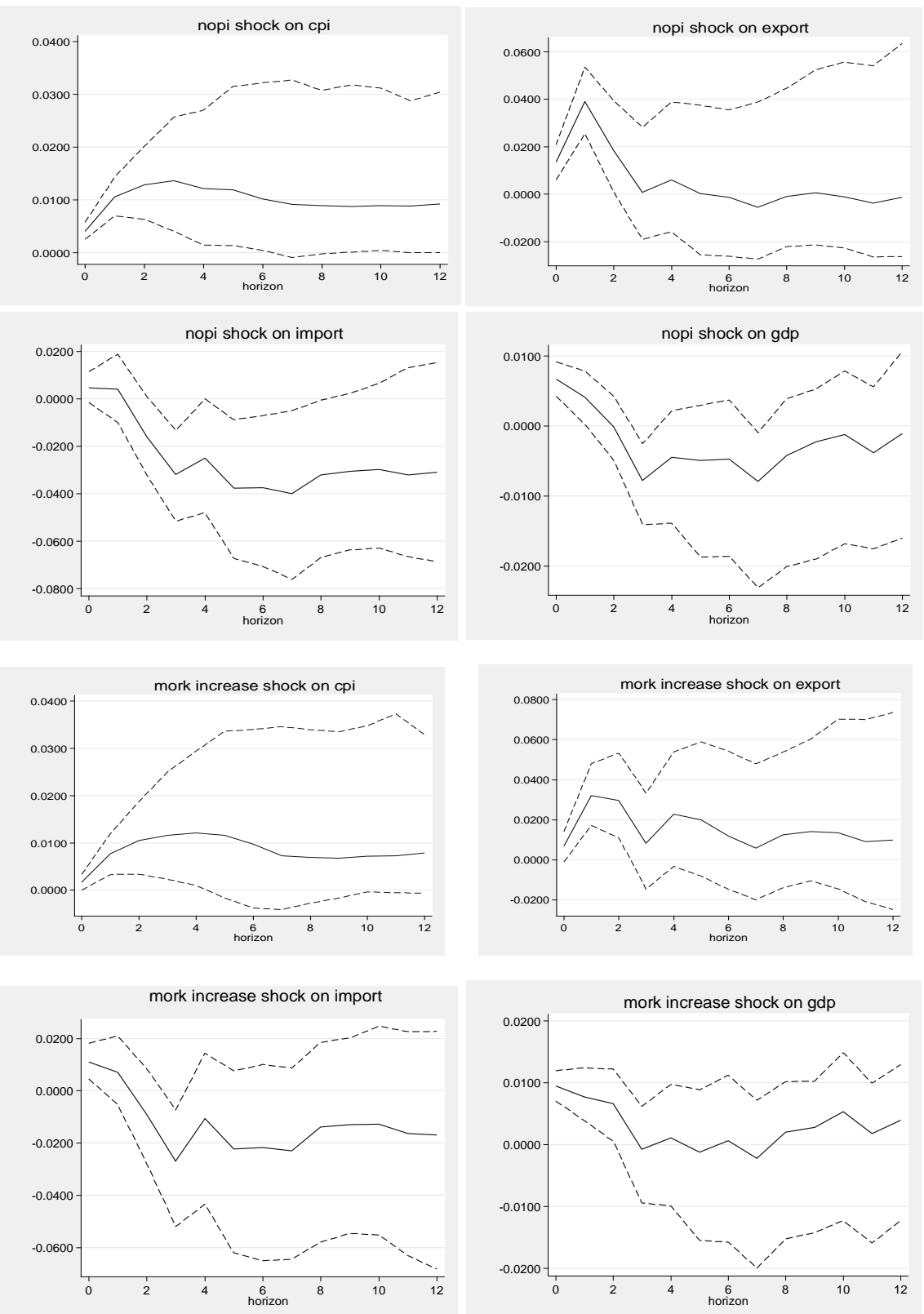

Figure 1. Impulse Responses of Oil Price Shocks Variables on CPI,EXPORT, IMPORT \& GDP (cont'd) 
Oil Price Shocks and Macroeconomic Activities in Asean-5 Countries: A Panel VAR Approach
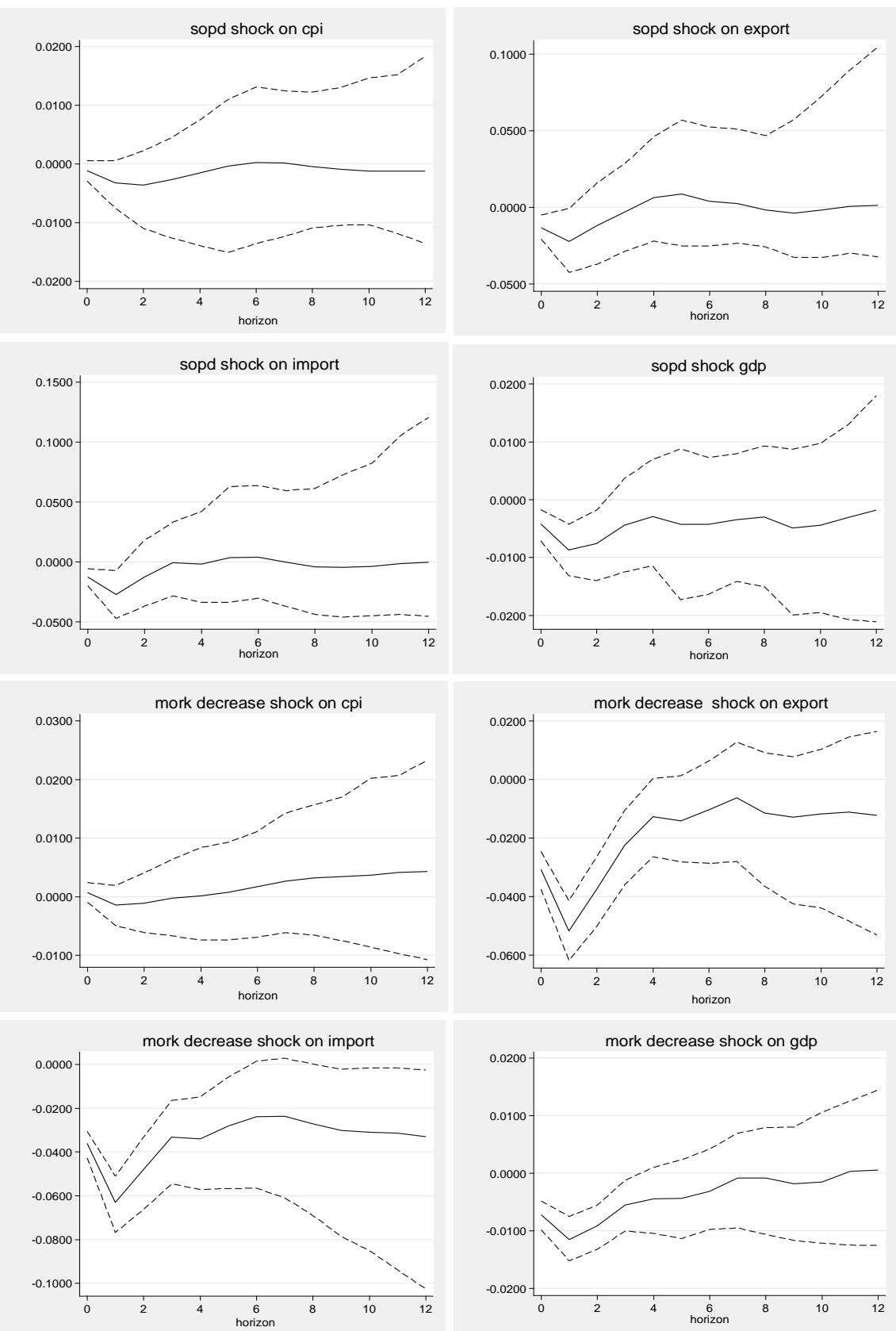

Figure 1. Impulse Responses of Oil Price Shocks Variables on CPI,EXPORT, IMPORT \& GDP (cont'd) 
Next, the $2^{\text {nd }}, 3^{\text {rd }}$ and $4^{\text {th }}$ rows in Figure 1 show the results of one standard deviation shock to the three non-linear oil price increase measures (SOPI, NOPI \& MORK INCREASE) respectively. Generally, the results are similar across the three price measures. Inflation (CPI) reacts positively to oil price increases in the short run. $\mathrm{CPI}$ increases between the first and fourth quarter before it moves back to its pre-shock level in the $6^{\text {th }}$ quarter. The impacts are statistically significant for all three oil price increase measures. A shock in CPI contemporaneously affects real exports in ASEAN-5. Rising domestic prices affect the competitiveness of ASEAN-5 products and foreign trade. Although EXPORT increase significantly for two quarters after the initial positive shocks, it subsequently decline for the next 10 quarters. The decrease in EXPORT however is not statistically significant. The medium- and long-term decreasing trend (as observed from IRFs) may be due to weak consumer demand from ASEAN-5's major trading partners, namely the US, Japan and China, consequent upon the positive oil price shocks. The adverse impacts of oil price increase on these countries, especially the US, raise inflation and reduce the real disposable income of consumers, thus limiting their demand for imports.

In a panel that includes two oil exporting countries (namely Malaysia and Indonesia) and an oil-refinery country (i.e. Singapore), the impact of positive oil price shocks on ASEAN-5's real GDP contradicts the finding from Berument et al. (2010). The IRFs show that real GDP decreases significantly for two quarters following a one standard deviation shock to the three non-linear oil price increase measures. Real GDP never return to its pre shock level by the end of the 12-quarter period. Impacts on real import (IMPORT) are greatly identical to the impacts on real GDP. IMPORT decreases continuously for six quarters following the increase in oil prices. These outcomes are not unexpected because oil export accounts for less than $9 \%$ of ASEAN-5 GDP. The relatively small share of oil to the economy makes ASEAN-5 no less vulnerable than some oil-importing countries to oil price shocks. While several countries in ASEAN-5 have profited from increased world energy prices, its export-oriented economies make it vulnerable to fluctuations in global demand and the performance of its trading partners. The slowdown of the US and China economies in recent years are expected to impact export growth adversely resulting in lower forecast GDP growth as simulated by the IRF analysis.

For SOPD and MORK DECREASE specifications, Figure 1 (referring to $5^{\text {th }}$ and $6^{\text {th }}$ rows) shows that the responses of CPI, real exports, real imports and real GDP to a one standard deviation negative shock are not constantly the opposites of those obtained from the increase specifications. This is true mainly for the responses of GDP and IMPORT to oil price decrease. Oil price decrease has a negatively significant impact on GDP between the first and second quarters, similar to that of positive oil price shock impacts on GDP. However, the response on GDP is not statistically significant over the long term. Likewise, real imports decline in the first quarter after the initial shock but rebounds afterwards. IMPORT increases between the $1^{\text {st }}$ and $6^{\text {th }}$ quarters when using MORK DECREASE measure and this increase is 
statistically significant. Impacts on CPI are not statistically significant for most quarters but EXPORT exhibit significant increase between the $1^{\text {st }}$ and $3^{\text {rd }}$ quarters after a negative shock to the oil price when using MORK DECREASE measure.

When comparing the results between the positive (increase) and negative (decrease) non-linear IRFs simulations, the paper in general finds noticeable differences between these two approaches. In other words, there is evidence of an asymmetric relation between oil price shocks and macroeconomic activities in ASEAN-5. In several cases, the IRF plots of the negative non-linear specifications (SOPD \& MORK DECREASE) are not constantly the opposites of the results obtained from the positive non-linear measures (NOPI, SOPI \& MORK INCREASE). This is true particularly for shocks to IMPORT and GDP. Nevertheless, the paper does find some similarity on the responses of EXPORT and CPI to positive and negative oil price shocks (i.e. the results are the opposites between the two specifications). Positive oil price shocks (as observed from SOPI and MORK INCREASE) cause EXPORT to increase for two quarters but subsequently decline until the $6^{\text {th }}$ quarter before returning to its pre-shock level in the $10^{\text {th }}$ quarters. In contrast, the response of EXPORT to oil price decreases exhibit significant decline in the 1st quarter before improving in the subsequent quarters. Similarly, the responses of CPI to a one standard deviation negative shock (when using SOPD and MORK DECREASE measures) are not considerably different than those obtained from the oil price increase specifications.

\subsection{Robustness Checks}

The IRFs obtained from the baseline ordering is based on the assumption that prices are flexible - [Oil Price variable, CPI, EXPORT, IMPORT and GDP]. This ordering allows the price level (CPI) to adjust contemporaneously to shocks in oil prices. For robustness checks, the paper estimated IRFs with for symmetric and asymmetric definition of oil prices shocks. The second alternative ordering follows the price rigidity assumption - [Oil Price variable, EXPORT, IMPORT, CPI and GDP]. The IRFs obtained from this ordering ${ }^{3}$ are comparable to the IRFs from the baseline ordering. In spite of the alternative ordering based on the price flexibility and price rigidity, responses of the four macroeconomic variables to an oil price shock however remains unchanged. Thus, results from IRF presented earlier are robust to changes in ordering of the variables and the responses of each macroeconomic variable to shocks in oil prices in the short- and long run are justified.

\subsection{Variance Decomposition Analysis}

Variance decomposition represents the panel VAR system dynamics by providing information about the relative importance of each random innovation to the variables in the model. It shows how many of the unanticipated changes or variations of the variables in the model can be explained by various shocks. Table 3

\footnotetext{
${ }^{3}$ Results for the robustness tests are available upon request from the author.
} 
shows the variance decomposition of the VAR model using linear and non-linear oil price specifications. The columns in Table 3 represent the source of oil price shocks using different oil price specifications in the VAR system. The rows represent the percentage of the change in each variable that is the result of oil price shock which is shown $5,10,15$ and 20 quarters in the future.

\section{Table 3. Variance decomposition}

\begin{tabular}{|c|c|c|c|c|c|c|c|}
\hline & \multicolumn{7}{|c|}{ Sources of shocks (\%) } \\
\hline & & DLOGROIL & NOPI & MORK+ & SOPI & MORK- & SOPD \\
\hline \multirow{20}{*}{ 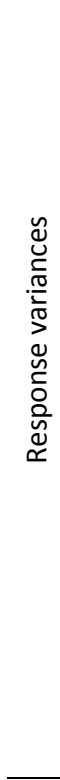 } & \multicolumn{7}{|l|}{ CPI } \\
\hline & 5/QTR & 3 & 8 & 6 & 7 & 0 & 0 \\
\hline & 10/QTR & 3 & 8 & 6 & 7 & 0 & 0 \\
\hline & 15/QTR & 3 & 9 & 7 & 8 & 1 & 0 \\
\hline & 20QTR & 2 & 10 & 7 & 9 & 2 & 0 \\
\hline & Export & & & & & & \\
\hline & 5/QTR & 2 & 6 & 7 & 6 & 20 & 2 \\
\hline & 10/QTR & 11 & 3 & 4 & 3 & 11 & 1 \\
\hline & 15/QTR & 8 & 2 & 3 & 2 & 8 & 0 \\
\hline & 20QTR & 6 & 1 & 2 & 1 & 6 & 0 \\
\hline & Import & & & & & & \\
\hline & 5/QTR & 6 & 5 & 2 & 6 & 20 & 2 \\
\hline & 10/QTR & 3 & 10 & 3 & 9 & 13 & 0 \\
\hline & 15/QTR & 2 & 9 & 2 & 8 & 10 & 0 \\
\hline & 20QTR & 1 & 8 & 2 & 7 & 9 & 0 \\
\hline & GDP & & & & & & \\
\hline & 5/QTR & 7 & 3 & 4 & 3 & 7 & 3 \\
\hline & 10/QTR & 4 & 3 & 2 & 3 & 4 & 3 \\
\hline & 15/QTR & 4 & 2 & 2 & 2 & 4 & 3 \\
\hline & 20QTR & 4 & 2 & 3 & 2 & 3 & 2 \\
\hline
\end{tabular}

For linear specification (DLOGROIL), oil price shocks contribute a relatively small share to the variation of $\mathrm{CPI}$, averaging around 3\% throughout the 20-quarter period. The largest effect of an oil shock on a variable's variation is through EXPORT, accounting for approximately $11 \%$ in the 10 th quarter and $8 \%$ in the 15 th quarter. For GDP, crude oil prices account for $4 \%$ of volatility between the 10 th and 20 th quarters. Shocks to oil price account for $6 \%$ of shocks in IMPORT in the fifth quarter, decreasing to $3 \%$ in the tenth quarter.

For non-linear oil price measures, both oil price increases and decreases affect the volatility of macroeconomic variables in the model to varying degrees. By and large, the contribution of positive oil price changes to each variable's variation is greater than negative oil price changes, especially for inflation. For inflation fluctuations, positive oil price shocks have a persistent short- and long-run role compared to negative oil price shocks. While negative oil price shocks (MORK DECREASE) account for just $1 \%$ and $2 \%$ of variances in inflation in the 15th and 20th quarters, positive oil price shocks (MORK INCREASE) explain about $7 \%$ of inflation 
fluctuations for the same period. This again confirms the inflationary pressures observed during periods of high oil prices.

The other important aspect of asymmetric oil price shocks is in their effects on EXPORT and IMPORT fluctuations. While negative oil price shock (SOPD) play almost no role in variations in these variables, variations in EXPORT and IMPORT due to MORK DECREASE measure explained around $20 \%$ in fifth quarter before decreasing to around $11 \%-13 \%$ in the tenth quarter. This supports the statistically significant impact of MORK DECREASE shocks to EXPORT and IMPORT presented in the IRFs section earlier. Conversely, positive oil price shocks (NOPI and SOPI) have moderate effects in the short term. Positive oil price shocks explain about $6 \%$ of fluctuations in EXPORT for the fifth quarter after the shock, decreasing to about $3 \%$ in the tenth quarter after the shock. Similarly, the contribution of NOPI and SOPI to variations in IMPORT averaged around $5 \%$ in the fifth quarter, increasing to about $8 \%$ in the 15 th quarter after the shock.

When comparing the results obtained from the variance decomposition, evidence of asymmetric relationship between oil prices and macroeconomic can be supported. This is because, in most cases, the contributions of positive oil price shocks on the macroeconomic variables are higher than the negative oil price shocks. In other words, there is a difference between the effects of positive and negative oil price shocks on economic activities, pointing to an asymmetric relationship between oil prices and the macroeconomic variables in ASEAN-5, supporting the evidence previously found in the IRFs simulations.

\section{Conclusion}

This paper studies the effects of oil price shocks on the real economic activity of ASEAN-5. It has focused on the relationship between oil prices and GDP growth, analysed in terms of VAR using four specifications, namely a linear model and three leading non-linear specifications proposed in the literature. IRFs and variance decomposition were estimated to assess how oil price shocks move through major channels of the ASEAN-5 economies and the contribution of shocks to the variability of the variables in the system. Four macroeconomic variables were taken into consideration: real gross domestic product (GDP), real export (EXPORT), real import (IMPORT) and inflation (CPI), together with four real oil price specifications.

The IRF obtained from the linear oil price specification (DLOGROIL) indicated that oil price movements lead to declines in GDP in the long term after experiencing growth in the short term. However, only marginal impacts are seen in CPI. Analysis from the non-linear oil price specifications produced comparable results. Hamilton's (1996) NOPI, Lee et al.'s (1995) SOPI, and Mork's (1989) positive oil price shock measures negatively affect output growth both in the short term and in the long term. For non-linear oil price decrease specifications, real output responds 
negatively in the short term before recovering to its pre-shock level in the long term.

The significant difference between the effect of oil price increases and decreases (as observed from IRF) suggest an asymmetric relationship between aggregate economic activity and oil prices. Additionally, the variance decomposition estimated from the non-linear VAR model also shows that oil price increases contribute around the same proportion to the variability of GDP, real exports, real imports and inflation than that of oil price decreases. This supports the asymmetric relationship between oil prices and macroeconomic variables for the ASEAN-5 economies found in the IRFs analysis.

Results from the panel VAR estimation reveal that GDP responds negatively to oil price increase in the long term without experiencing significant growth in the short term. Though Malaysia and Indonesia produces and exports oil while Singapore has a booming oil refinery industry, the contribution to the economies is relatively small. Therefore, the economic stimulus provided by higher oil-export earnings in these countries would be more than outweighed by the depressive effect of higher prices on economic activity in importing countries. In other words, the windfall revenue from the oil sector may not be sufficient to cushion the economy from slowdown experienced by neighbouring and major trading partners. Given these results, forthcoming fiscal policies must not assume that future effects of upcoming oil shocks will be the same as in the past. Nevertheless, analysing economic policy reactions amidst these shocks will show how effective the chosen monetary or fiscal policies are in minimising adverse effects.

The recent hike in world crude oil prices has prompted the ASEAN member states (AMS) to encourage the use of alternative energy sources such as natural-gas vehicles (NGV) and bio-diesel. In recent years, the AMS made considerable effort to tap the vast renewable energy resources in the region. Several countries introduced feed-in-tariffs or regulations for renewable energy as well as other supportive policies, for example tax and customs exemptions or tax holidays.

\section{References}

Arellano, M., \& Bover, O. (1995). Another Look at the Instrumental Variable Estimation of Error-Components Models. Journal of Econometrics, 68(1), 29-52. http://dx.doi.org/10.1016/0304-4076(94)01642-D

Basnet, H. C., \& Upadhyaya, K. P. (2015). Impact of Oil Price Shocks on Output, Inflation and the Real Exchange Rate: Evidence from Selected ASEAN Countries. Applied Economics, 47(29), 3078-3091. http://dx.doi.org/10.1080/00036846.2015.1011322

Berument, M. H., Ceylan, N. B., \& Dogan, N. (2010). The Impact of Oil Price Shocks on the Economic Growth of Selected Mena1 Countries. The Energy Journal, 31, 149-176. http://dx.doi.org/10.5547/issn0195-6574-ej-vol31-no1-7 
Oil Price Shocks and Macroeconomic Activities in Asean-5 Countries: A Panel VAR Approach

Breitung, J. (1999). The local power of some unit root tests for panel data (No. 1999, 69). Discussion Papers, Interdisciplinary Research Project 373: Quantification and Simulation of Economic Processes.

Burbidge, J., \& Harrison, A. (1984). Testing for the Effects of Oil-Price Rises Using Vector Autoregressions. International Economic Review, 25, 459-484. http://dx.doi.org/10.2307/2526209

Cavalcanti, T., \& J. T. Jalles (2013). Macroeconomic Effects of Oil Price Shocks in Brazil and in the United States. Applied Energy, 104, 475-486. http://dx.doi.org/10.1016/j.apenergy.2012.10.039

Cunado, J., \& Perez De Gracia, F. (2005). Oil Prices, Economic Activity and Inflation: Evidence for Some Asian Countries. The Quarterly Review of Economics and Finance, 45, 65-83. http://dx.doi.org/10.1016/j.qref.2004.02.003

Dornbusch, R., Fischer, S. \& Startz, R. (2001). Macroeconomics. New York, Mcgraw Hill.

Ekşi, i. H., Izgı, B. B., \& Şentürk, M. (2011). Reconsidering the Relationship between Oil Prices and Industrial Production: Testing for Cointegration in some of the OECD Countries. Eurasian Journal of Business and Economics, 4(8), 1-12.

Eltony, M. N., \& Al-Awadi, M. (2001). Oil Price Fluctuations and Their Impact on the Macroeconomic Variables of Kuwait: A Case Study Using A VAR Model for Kuwait. International Journal of Energy Research, 25, 939-959. http://dx.doi.org/10.1002/er.731

Engemann, Kristie M., Kevin L. Kliesen., \& Michael T. Owyang (2010). Do Oil Shocks Drive Business Cycles? Some U.S. and International Evidence. Working Paper, Federal Reserve Bank of St. Louis.

Farzanegan, M. R., \& Markwardt, G. (2009). The Effects of Oil Price Shocks on the Iranian Economy. Energy Economics, 31, 134-151. http://dx.doi.org/10.1016/j.eneco.2008.09.003

Ferderer, J. P. (1996). Oil Price Volatility and the Macroeconomy. Journal of Macroeconomics, 18, 1-26. http://dx.doi.org/10.1016/S0164-0704(96)80001-2

González, A., \& Nabiyev, S. (2009). Oil Price Fluctuations and its Effect on GDP Growth: A Case Study of USA and Sweden. Jönköping University: Jönköping International Business School. Retrieved from http://www.Diva-Portal.Org/Smash/Get/Diva2:202051/Fulltext01.Pdf Hamilton, J. D. (1983). Oil and the Macroeconomy Since World War II. Journal of Political Economy, 91, 228-248. http://dx.doi.org/10.1086/261140

Hamilton, J. D. (1988). A Neoclassical Model of Unemployment and the Business Cycle. The Journal of Political Economy, 96, 593-617. http://dx.doi.org/10.1086/261553

Hamilton, J. D. (1996). This Is What Happened To The Oil Price-Macroeconomy Relationship. Journal of Monetary Economics, 38, 215-220. http://dx.doi.org/10.1016/S03043932(96)01282-2

Hamilton, J. D. (2003). What Is an Oil Shock?. Journal of Econometrics, 113, 363- 398. http://dx.doi.org/10.1016/S0304-4076(02)00207-5

Hamilton, J. D. (2011). Nonlinearities and the Macroeconomic Effects of Oil Prices. Macroeconomic Dynamics, 15(S3), 364-378. http://dx.doi.org/10.1017/S1365100511000307

Hunt, B., Isard, P. \& Laxton, D. (2001). The Macroeconomic Effects of Higher Oil Price. IMF Working Paper International Energy Agency "IEA Annual Report" Various Years

Im, K. S., Pesaran, M. H., \& Shin, Y. (2003). Testing for unit roots in heterogeneous panels. Journal of econometrics, 115(1), 53-74. 
Jbir, R., \& Zouari-Ghorbel, S. (2009). Recent Oil Price Shock and Tunisian Economy. Energy Policy, 37, 1041-1051. http://dx.doi.org/10.1016/j.enpol.2008.10.044

Jiménez-Rodrígueza, Rebeca., \& Marcelo Sánchez (2005). Oil Price Shocks and Real GDP Growth: Empirical Evidence for Some OECD Countries. Applied Economics, 37, 201-228.

Ju, K., Zhou, D., Zhou, P., \& Wu, J. (2014). Macroeconomic effects of oil price shocks in China: An empirical study based on Hilbert-Huang transform and event study. Applied Energy, 136, 1053-1066. http://dx.doi.org/10.1016/j.apenergy.2014.08.037

Jumah, A., \& Pastuszyn, G. (2007). Oil Price Shocks, Monetary Policy and Aggregate Demand in Ghana. Economics Series.

Leduc, S., \& Sill, K. (2004). A Quantitative Analysis of Oil-Price Shocks, Systematic Monetary Policy, and Economic Downturns. Journal of Monetary Economics, 51, 781-808. http://dx.doi.org/10.1016/j.jmoneco.2003.09.004

Lee, K., Ni, S., \& Ratti, R. A. (1995). Oil Shocks and the Macroeconomy: The Role of Price Variability. The Energy Journal, 16, 39-56. http://dx.doi.org/10.5547/ISSN0195-6574-EJVol16-No4-2

Levin, A., Lin, C. F., \& Chu, C. S. J. (2002). Unit root tests in panel data: asymptotic and finitesample properties. Journal of econometrics, 108(1), 1-24.

Love, I., \& L. Zicchino (2006). Financial Development and Dynamic Investment Behaviour: Evidence from Panel VAR. The Quarterly Review of Economics and Finance 46(2), 190-210. http://dx.doi.org/10.1016/j.qref.2005.11.007

Lütkepohl, H. (2007). General-to-specific or specific-to-general modelling? An opinion on current econometric terminology. Journal of Econometrics, 136(1), 319-324.

Mallick, S. K., \& Mohsin, M. (2007). On the Effects of Inflation Shocks in a Small Open Economy. Australian Economic Review, 40(3), 253-266. http://dx.doi.org/10.1111/j.14678462.2007.00450.x

Mallick, S. K., \& Mohsin, M. (2010). On the Real Effects of Inflation in Open Economies: Theory and Empirics. Empirical Economics, 39(3), 643-673. http://dx.doi.org/10.1007/s00181-009-0328-0

Mork, K. A. (1989). Oil and the Macroeconomy When Prices Go Up and Down: An Extension of Hamilton's Results. Journal of Political Economy, 97, 740-744. http://dx.doi.org/10.1086/261625

Negi, P. (2015). Impact of Oil Price on Economic Growth: A Study of BRIC Nations. Indian Journal of Accounting, 47, 1.

O'neill, P. \& Terrell. (2008). The Role of Higher Oil Prices: A Case of Major Developed Countries. Research in Finance. Emerald Group Publishing Limited, 287-300. http://dx.doi.org/10.1016/s0196-3821(07)00211-0

Rahman, S., \& Serletis, A. (2010). The Asymmetric Effects of Oil Price and Monetary Policy Shocks: A Nonlinear VAR Approach. Energy Economics, 32(6), 1460-1466. http://dx.doi.org/10.1016/j.eneco.2010.06.003

Rasche, R. H. \& Tatom, J. A. (1981). Energy Price Shocks, Aggregate Supply and Monetary Policy: The Theory and International Evidence. Carnegie-Rochester Conference Series on Public Policy, 14, 9-93. http://dx.doi.org/10.1016/0167-2231(81)90002-6

Vu, T. K., \& Nakata, H. (2014). The Macroeconomic Effects of Oil Price Fluctuations in ASEAN Countries: Analysis Using a VAR with Block Exogeneity (No. 619). 